\title{
Youth in conflict in the Horn of Africa: A comparative analysis of mungiki in Kenya and Al-shabaab in Somalia
}

\section{Hannah Muthoni}

\begin{abstract}
Youth constitute the largest percentage of the total world population and are considered core to the development of society. However, even with the large numbers, researches on youth in Africa tend to be skewed on employment and labour distribution, education and human development. Outside these formalized sectors, youth are studied as the most controversial group based on their behavior and seemingly misplaced roles. The place of youth in conflict in Africa is thus unexplored as available research focuses more on child soldiers in relation to recruitment, effects of conflicts, disarmament and reintegration. Beyond this, youth in conflict are studied in relation to violence and delinquency particularly in the United States of America and Europe and hardly in Africa. This is despite the growing involvement of youths in conflict as militias, rebels, vigilante groups as well as victims. This article explores the place of youths in conflict of post-colonial Africa where their role has increasingly grown. As a comparative analysis, it uses the case study of $A l$-shabaab in Somalia and Mungiki in Kenya
\end{abstract}

Key words: Youth, Mungiki, Al-Shabaab, Kenya, Somalia.

\subsection{Introduction}

During the early years of independence in the 1960s and 1970s, youth or young people in Africa were not seen a serious challenges to the development of the newly independent states. Thus, unemployed, uneducated and idle youth were not a major target for governments, international community as well as for local and international funding institutions (Mkandawire, 
1996). This perception has changed over the years as countries in Africa continue to witness rapid growth of youthful populations combined with high levels of unemployment, economic stagnation, unstable governments, poverty and rise of global system. These circumstances have considered a receipt for youths to get in violent activities in search for solutions (Kobia, undated). The situation has been wanting in countries where the political, economic and social systems are non-existence, weak or insufficient to deal with armed conflict and violent situations.

In armed conflict, youth as active participants are depicted as missing in action. They are only seen as tool of manipulation by the elite. This argument, grossly narrow the roles of youth in conflict and rationalizes the passive role of youth hence making youth victims. This paper suggests that youth are active independent actors in conflict. It also argues that since generational categories are not stable but are constantly produced and reproduced, active participation of youth in conflict can sustain conflict and violent situations for a long period. When debated in the mainstream media, youth are depicted either as victims or reactionary groups/perpetrators. As victims, they are the ones who are adversely affected by economic restructuring as young people end up being 'marginalized' or 'excluded group' from education, healthcare, salaried jobs and status of 'adulthood' (Mkandawire, 1996). As reactionary groups/perpetrators, they are seen as a social group that responds to poor policies of their government that ignore, exploit or exclude them. While as reactionary groups/perpetrators, they may be involved in violent activities they are not seen as a threat to peace and human security but as the exploited (Munene, 2011). However, as discussed later, youth in armed conflict are a threat to human security and global peace. Moreover, as this paper shows, unless the role of youth in conflict is evaluated with youth as a social entity, they can be basis for a culture of violence.

\subsection{Conceptions of youth}

Generally, the term youth is used to refer to any person between the ages of 15-24 years (UN, 1996). However, differences continue in the way national statistics programmes define and measures youth. Furthermore, youth as a generational category is neither flexible nor stable but it is continuously produced and reproduced. This lack of concise definition has led scholars such as 
Bourdieu, to states that 'youth is just a word' (Bourdieu, 1993). In terms of numbers, out of 6.8 billion world population (UN, 2009), 1.2 million are young people between 15 and 24 years. According to the 2009 population data, Africa alone has a total of 1.4 billon people with young,

Historically, youth is understood in relation to societies and cultures. This implies that in each society and in every culture there are benchmarks used to determine who is and is not a youth. To some, it's certain cultural practices while to others it is the age bracket outside which one is dismissed as an adult or a child. Still in other cultures, it is the association with truancy, criminality, mischief and violence that defines a youth. Besides the criminal associations, the first two benchmarks have been the most common features of understanding and defining a youth. However, operational definition and nuances of the term youth often vary from country to country and is dependent on specified socio-cultural, institutional, economic and political factors. This implies that the term youth is socially and culturally constructed. This gives rise to a number of conceptions of the term youth which include political, cultural/traditional, aesthetic, artistic, biological, and legal.

A cultural/traditional youth is one who is defined in accordance to traditional practices that mark the transition from one stage of life to another through the process of rite of passage. These traditional practices involve initiation practices such as removal of certain organs of the body, teeth or put certain marks on the body. One of the most common initiation practices common among African communities is circumcision that is carried out by among others the Maasai, Gikuyu, Abaluhyia, and Kalenjins of Kenya. In this regard, human development is seen to involve three stages in life that is; childhood, puberty and adulthood. These stages not only mark changes in the human body but are also mark stages at which new responsibilities are acquired such as marriage. However, with the influence of modernity, there exist the so-called cultural youth who despite having gone through the initiation have not fulfilled their cultural responsibilities. Hence, even at the age of 40 s they are still being referred to as youth. While some of them, it is a matter of choice to others it is a result of the need to pursue certain goals in life such as education and career.

For African communities, failing to fulfill the traditionally defined norms is unaccepted and subsequently these groups of youth are collectively classified as defiant youth. The current 
President of Botswana is a good example of a defiant youth. Nonetheless his current position in Botswana as the head of state and the chief of Bamagwato people has forced him to try and fulfill the Bamagwato's ethnic tradition that defines marriage as an obligation for anyone assuming traditional duties (ABC News, 2010). This denotes that while cultural/traditional youth may abscond and ignore traditional practices, circumstances do force them to adhere to cultural standards.

A legal youth is the most common definition used across the world. A legal youth refers to any social group that falls between specified age brackets. According to the United Nation Convention on Child rights a youth is defined as 'young persons (boy/girl) of ages between eighteen and thirty five years (18-35) (UN, 1996). The third conception of a youth is derived from politics and the political history of a country. This is a political youth. Political youth include people who despite having passed the legal bracket (18-35 years) of a youth, still classify themselves as youth. For instance, this category is common in Kenya where politicians often categorize themselves as youth more so during the electoral campaign period. Terms such as young generation, young turks, Vs. the old turks are common political statements. But the basic question is what the basis of this conceptualization? The basis of this conceptualization can be understood from three perspectives. The first group of political youth includes those who perceive themselves as being youth in relation to political history of Kenya. In their case the history of Kenya is limited to independence and the period thereafter.

The second group, emphasis the length of time one has served in the government. Consequently, those who served longest and in this case both in Kenyatta's and Moi's government are categorized as the old generation while those who served the shortest period of time or never served are classified as the youth. The third view identifies with people of 30 years and below in relation to the incumbent leadership. If during 30 years of their life these youth have not known any other leaders than the incumbent, then, it goes without saying that the incumbent is a representation of old generation. In cases of political protests and revolutions, the incumbent become the bad as evidenced in Libya with Muammar Gaddafi and Egypt with Hosni Mubarak. While the idolized leaders of these protests and revolutions are not young Turks that is El-Baradei, 
68 years and Sahel in Egypt and Libya respectively. The mere fact that those aged 30 years and below have never been lead by them earns them the title of a youth.

This group is however not without contradictions particularly when the political climate appears to discredit or question them. A common practice with political youth in Kenya is when guarantee to win a political office is dictated by the association of political youth with the older generation. Where this applies as it sometimes, the political youth then considers the older politicians as being politically correct therefore becoming bed-fellows. Contrastingly, when questioned about their illogical political outbursts, poor leadership and failure to deliver on their campaign promises by the legal youth, they blame the old generation. When the question of giving legal youth opportunity to lead, the political youth are quick to switch to cultural cards of equating grey hair with wisdom and thus the legal youths are leaders of tomorrow. The irony of this political gimmick is that the cultural niche of age that political youth fall back to literally disqualifies them when compared to the older generation.

Remaining youthful and being a youth is equated to people in the "process of becoming rather than being'. This state of becoming makes people desire to be in it for as long. However, as people age the body tissues loses water causing human skin to lose the youthful and subsequent physical features of a youth. Beyond this, the depletion of ozone layer and climate change resulting from increase in greenhouse gases in the atmosphere causes skin to age faster than normal (Urbach, 1991). Because of this, scientists, dermatologist and cosmetologists have come up with means of ensuring that though the body ages one can still pride himself or herself of being a youth. The solutions given by the scientists, dermatologists and cosmetologists have lead to the rise of a new conception of a youth that is aesthetic. This category cuts across all the divides of conceptions of youth that is biological or calendar, legal, cultural, and political.

Some of the most common methods of changing a sagging and aging skin include plastic surgery, bleaching of skin, cosmetic surgery, cosmetics, exercise and botox. Examples of aesthetic youth includes; Oprah Winfrey, the late Michael Jackson, Muammar Gaddafi of Libya, Madonna, President Obama, Arnold Schwarzenegger, Hilary Clinton and Angelina Jolie among others. For 
the legal youth, the aesthetic youth are perceived as good role models. This has caused some legal youth to ape the lifestyle of aesthetic youth.

Beyond these conceptions, identifying with youth culture is becoming a common trend to be classified as a youth. In Kenya for instance, speaking the slang language, Sheng (a mixture of Kiswahili and English language with variants from other local or international dialects) that is common among the youth determines whether one is a youth or an old buddy. Another means of being identified as a youth. For example Yoweri Museveni of Uganda who is past the age of a youth legally and culturally has in the recent past associated himself with the youth culture. In 2010 Museveni used youth culture in this case rap music to attract the support of the youth in his political campaign (Njoroge, 2010). His title of a youth was however short-lived as after elections the 'rapping president' recoiled into his political title. In Kenya, the issue of young or youthful leaders is an endless discussion. Currently, one of the Member of Parliament for Makadara constituency Mike Sonko has been in the forefront for accusing the rest of the Members of Parliament who in his view have failed to deliver in parliament because of their age and lack of alertness. In his view, he is in parliament to awaken the 'sleeping legislative members' and the best way is to dress youthful besides his youthfulness (Shiundu, 2011). Hence, to him the issue is not having young people in parliament, but dressing youthful. This raises concern for Kenya as it related to youth leadership and their credibility as representative of their people.

\subsection{Overview of youth in armed conflict}

In Africa, the images of youth as the most vulnerable and innocent social category have dominated mainstream sectors. Therefore, youth involvement in armed conflict becomes quiet alarming and causes great concern. This is because, vulnerability and innocence is seen as resulting from being the protected, lack of resources and power of influence. In such an environment the participation of youth in armed conflict and violence is understood in relation to achievement of adult dreams be it the political, economical, religious or cultural. The youth are therefore a tool or a resource for adults. There is no where the idea of youth as tools for achieving goals is more relevant that in politics where access to social, political and economic goodies is dependent on politics of manipulation and patronage (Oloo, 2010). When politics of manipulation 
and patronage are played out in conflict situations, the youth are reduced to passive actors, solely dependent on others. This may not be the case in conflict and violent situation where youth have been active participants (UNDP and GoK, 2007). Moreover, defining the youth as tools for political gain obscures the direct involvement of youth in conflict and violence as independent actors. This notion further help in upholding conventional studies that limits the role of youth in conflict to child soldiers and an unruly social group.

Upholding these conventional views in Africa where over 70 conflicts have taken place since 1970s is wanting. This is because despite the limitation of data, youth have been active participants in conflict and violence as witnessed in Kenya, Sudan, Sierra Leone, Malawi, South Africa, Somalia and Liberia. And although conflicts are natural to every society, the increased and adverse effects of conflicts with youth as active participants is exasperating (Mwagiru, 2005). Added to the involvement of the youth in African conflicts are the increased and multiplicity of actors in a single and multiple conflicts. Examples of actors include the state and its mercenaries, militias, rebels, vigilantes, criminal bands, ethnic and religious armed wings, private security companies among others. These actors are what Okumu and Ukelegbe (2010) collectively refer to as armed non-state groups (ANSGs) who have been 'key players in the political violence that have severely undermined human security in Africa (Okumu and Ukelegbe, 2010; 1). In all these groups, youth who constitute the largest percentage of the total national populations in most countries tend to dominate the membership and related activities.

In the context of social, political and economic challenges that tend to overshadow African states, the place of the youth has become a fundamental paradox. On one hand they are viewed as both makers and breakers of society while they are simultaneously being made and broken by the society (De Boeck and Honwana, 2005). Youth are thus two sides of the same coin. As makers of the society, they are studied alongside children as a heterogeneous group that contributes to the societal structures, norms, rituals and directions while they are being shaped by them (Biaya, 2000). As makers of the society, they also make themselves through inventive 'forms of selfrealization and an ingenious politics of identity (De Boeck, 1999). Politically, they make the society by acting as a political force, a source of resistance and resilience. 
The youth also act as breakers because of the risk factors that they engaged in. Some of these risks include drug use, alcohol, truancy, violence and unsafe sex. At the same time, by breaking expected societal norms, practices, rules and conventions they end up killing people, dehumanizing and harming others by their violent activities. Breaking also implies dismantling the chains of oppression as witnessed in South Africa where young people played a crucial role in 'breaking' the apartheid system. Currently, this breaking role is what Munene (2011) sees as being played out in the ongoing Arab revolutions. For Munene, the participation of the youth in the protest shows the role of the youth in 'breaking from an increasingly untenable existing condition' (Munene, 2011: 1). Additionally, they are also breaking the society as the same youth are 'turning against their parents and grandparents'.

In all, the youth are constantly shaping and shaking the society as they are also being shaped and shaken by the very society. In this process of being shaped and shaken the youth are pushed, coerced into different actions by existing structures and process some of which they have little or no control. Some of this includes the family, community, media, technology, state, conflict and war situations, religion, and global systems. Key to all these aspects is that the youth are constantly being broken down by exclusion, wars, unemployment, poverty, marginalization, and lack of access to education, denial of adulthood status among others (Dawes and Honwana, 1996). Collectively, these features of the youths of breaking, making, being made and being broken causes the youth, children and young people to be lumped together as a single heterogeneous group. This makes it difficult to grasp and pin down analytically the youth in armed conflict.

Other than the definition that is highly contested and categorically undefined, scholars and researchers have made frantic effort to explain why youth engage in armed conflict and violence in Africa. There are a number of factors contributing to the involvement of youth in armed conflict and violence. Firstly is the youth culture particularly the problem of unemployment, underemployment and the disaffection youth. This culture as noted by Comaroff and Comaroff (2005) depicts youth as undesirable and a social status that one tries to escape of which, one of the best ways is to engage in violence and armed conflict. Secondly, youth engage in violence and armed conflict because of the proliferation of small arms and illicit weapons. Still related to the 
proliferation of arms is the notion that access to small arms appears to have an empowering effect on alienated youth such as the marginalized, street children and the unemployed. Hence fighting as independent groups or alongside rebels, militias or government troops using AK-47 enlist a deeper means of empowerment than the youth culture and street life.

For youths who lack training, formal education and specialized skills involving oneself in armed conflict and violence become an easy way to earn a livelihood. The reason being war and violence offers an option that requires little or no skills neither capital investment while at the same time it provides quick returns. Hence, for frustrated youths both male and female, the gun gives them an informal way of controlling resources and gives them command with regard to money and power. Another reason related to existence of violent situations in a country. Long term conflict like those witnesses in Sudan, Somalia, Democratic Republic of Congo (DRC) and Sierra Leone affected generations causing people to live in protracted situations. Besides, the political, economic and social structures were destroyed. And with no other life known to the youths and with no incentives to deter them from engaging in violence, joining the warring groups is not a loss for the youth. That is why Chigunta (2002) argues that the youth have no personal properties or dependable employment thus they have the 'lowest opportunity cost in war'

According to a 2007 report by UNDP and the Government of Kenya, youth engage in armed conflict and violence if subjected to social and economic marginalization, unstable governments, poverty, insecurity, and development challenges. The widespread of drugs such as heroine and marijuana among others on war front and in urban areas also play a key role in enticing youth into armed conflict. The use of these drugs by youth in armed conflict erodes 'selfcontrol, enhance free-will behavior and encourage acts of bravery'. Chigunta (2002) further argues that the issue is not whether such youth have used drugs before but "the quality and intensity of use which increases considerably in war fronts" (2002: 19). Youth can also engage in violence and armed conflict in order to challenge the traditional political elite for control of the state. This has been the case in recent Egyptian and Tunisian revolutions. 
According to Engels (2010) youth engage in armed conflict and violence because they are less threatened by physical death than social death. Social death stem from material conditions of life that is closely linked to class based social inequalities that induce the gap between the youth and elderly. To escape social death, youth migrate to other countries, initiate or join an armed group as a way of finding a balancing act between social death and violent life.

Other factors explaining the participation of youth in armed conflict are: cultural practices such as cattle rustling among the pastoral communities in Kenya, collapse of the traditional family coping structures leaving a social void, for street children the tough life in streets develop in them qualities that makes them prey for rebels, vigilante groups and militias. Moreover, as a people lacking families to belong to, belonging to the fighting groups gives them a sense of belonging.

\subsection{Understanding the Al-shabaab}

Somalia is located in the eastern corner of Africa, known as the Horn of Africa. It is one of the African countries that have experienced the longest history of conflict in which youth have been active participants. The violent history in Somalia represents a deep contrast of the exceptional state that was romanticized at independence. The romanticization of an exceptional state was re-affirmed by Ali Mazrui in 1986 when he argued that while most African state were diverse and in search of national identity, Somalis were a people with a national identity in search of territorial unification. This was because of their ethnic, cultural, religious and linguistic homogeneity. An assumption of homogeneity state of Somalia was that Somalis being one people, differences would be easily solved however from the Somalia there were other issues cleave to hence making the common to different. The issues of cleavage are pointed out by Ahmed (2006) to include clan, sub-clans and political factions.

The conflict that led to the rise of militant groups such as Al-shabaab goes back colonial days when Somalia was divided into protectorates for the British, France and Italy. In British protectorate the Dervish $^{1}$ under the leadership of Sayyid Mohammed Hassan rose to fight for autonomy in 1899 (Issa- Salwe, 1994: 17). Their objective was to wage war against the infidels

\footnotetext{
${ }^{1}$ Dervish is an Islamic term referring to a people dedicated to the service of God and community
} 
and exert full control over Somalia. The British dominated the 20 years of violent history. The domination of the three colonial powers in Somalia continued to independence period. The youth were an influential actor from as early as 1940s. Munene (2010) points out that in preparation to independence the British had encouraged the formation of Somali Youth Club in 1943 and transformed to Somali Youth League. In 1960 the British released the British Somaliland to unite with Italian Somalia and form the greater Somalia an idea that failed to materialize.

The current situation in Southern Somalia that is an epitome of a failed state and a hotbed for continuous civil disturbance and international terrorism activities is traced back to the collapse of central government in 1991 with overthrow of Siad Barre. This was followed by rise of different groups that sought to take advantage of the situation to expand their influence. For close to 15 years, the local warlords most of the power but Islamic groups also became assertive. The Islamic groups had however started to develop their network to influence the country before 1960s. This was happening through the small groups of Somalis Salafi who studied the views Muslim Brothers in Egypt and Wahhabi teachings in Saudi (Shinn, 2010: 203). Upon their return in the country after independence, the Wahhabis created the The Unity of Islamic Youth (Wahdat al Shabaab al Islamiyya) and The Islamic Group (al Jama'a al Islamiyya) (ISS, 2010). The groups unite in 1982 to form the Islamic Courts Union (ICU) with fundamentalist features of salafism and wahhabism. The ICU carried terrorist attack in 1990s with support of Al-Qaeda. The ICU became more vocal in 2006 after it defeated the US sponsored warlords in Mogadishu known as the Alliance for Restoration of Peace and Counterterrorism (ARPC). By the end of 2006, the ICU had taken control of Central and Southern Somalia and threaten jihad against Ethiopia (Katagiri, 2010). As the Ethiopian backed troop together with the Transitional Federal Government (TFG) tried to wrestle the control of Mogadishu from the ICU, the Al-shabaab emerged as a distinct force from ICU.

Al-shabaab is an Arabic word for youth and an Islamic militant group that seeks to create an Islamic state in Somalia. Al-shabaab controls central and southern Somalia and has made it impossible for the TFG to govern the country. Majority of the Al-shabaab members are youths between the ages of 9 to 30 years of age. This means that majority of the members have grown through the conflict era of Somalia. Al-shabaab subscribes to global jihadist vision that believes in 
religious governance as the only solution to Somali problems. This ideology was re-affirmed in 2008 by the then spokesman of Al-shabaab Sheikh Muktar Robow, when he emphasized the importance of complying with Sharia law (Kataaib, 2008). In contrasting itself with ICU the Alshabaab touts its pan-Islamic ideology as opposed to the ICU's clan backed politics. As argued by the leadership of the Al-shabaab, ICU judged over individual tribes the Al-shabaab was made of many different tribes. This proposition by Al-shabaab shows that clan politics still have special place in Somalia. Globally, Al-shabaab recruits its members from all fronts locally, regionally and internationally (Thurston, 2010; Human Right Watch, 2000). Internally, Al-shabaab activities have involved relentless attacks of the TFG of Somalia and strict implementation of the Sharia law leading to denial of women right, committing of human atrocities, retributive justice and recruitment of child soldiers and youth.

The involvement of youth in violence in Somalia that targets next of kins is a contradiction of youth in Islam, which is a highly estimated group of people in the society. As noted in the Quran the youth are considered the best of the nation raised for mankind because they enjoin what is right and forbid the wrong (Sura, 110). Beyond this the earliest converts of Islam were young under the age of 30 such as Ali Ibn Abu Talib. Hence, the violence, atrocities and inhuman acts carried out by Al-shabaab is a contradiction of the youth in Islam. The foreign powers also play out in Somalia in four ways. These include 'transfer of strategy, tactics and ideology learned by Somali al Shabaab leaders during their association with the Taliban and al Qaeda' (Shinn, 2010; 206). Others include backing of proxy states by the Euro-powers, foreign recruitment by Al-shabaab and support of Al-shabaab by Eritrea. Thus, Al-shabaab youth are a force to reckon with due to their global linkages, history of growth in armed conflict and their youthfulness.

\subsection{Understanding the mungiki}

Unlike Somalia, Kenya has been a relatively peaceful country despite the inter-tribal conflicts that have been a common feature of Kenya's post-independence history. In Kenya's conflict history the youth have featured differently. For example, during the struggle for independence the youth participated actively through the Mau Mau movement (Oloo, 2010). Mau 
Mau leaders such as Dedan Kimathi and General China were said to have been below 35 years when they returned from the forest ${ }^{2}$. Youth participation in politics was however short-lived as after independence, the national multi-ethnic alliance disintegrated leading to rise of patrimonial politics that transformed the youth identity into weapons of the elders (Kagwanja, 2005: Lonsdale, 1986). And as their participation in politics and economy dwindled they were pushed into the periphery. This resulted into formation of youth wingers that were core to KANU politics which change later with the re-introduction of multi-party system. During this time, the youth were mobilized to form tribal militias which were used to wage war against the opposition who in return formed their own militias (Oloo, 2010; 43). Since then youth militant groups have become key to political history of Kenya with prominent groups such as Taliban, Jeshi la Mzee, Bagdad boys, Angola Musumbiji, Chinkororo and Mungiki becoming a new face of youth.

Mungiki is derived from Agikuyu word muingi-ki which means mob or masses of people (Nyatuga, 2001). The term muingi-ki also means full to the brim. When apply to people it means masses of people to the highest limit. Scholars agree that the Mungiki movement started in 1987 in Rift Valley province (Kagwanja, 2003). The original founders of Mungiki were a group of people who migrated from Central Province to Rift Valley Province to purchase land in late 1970s and $1980 \mathrm{~s}^{3}$. Organized in small groups, these people bought land in the region which they farmed collectively. According to Kiemo (2011) the reasons that made these people remain as muingi-ki was to enable them to farm their land together as well as survive the economic hardships and unconducive climate. With time, it became clear to these people other than their language, Gikuyu they did not have a tangible social units which they could hold on to. This was because in terms of religion they ascribe to different faiths. As a result, the Agikuyu traditional religion became the only socially shared common bond leading to the adoption of the Agikuyu traditional religious beliefs. The adoption of these religious beliefs was re-affirmed by their then leader Maina Njenga the father of the future leader of Mungiki, John Kamunya alias Maina Njenga who claimed that he had heard Ngai (God in Agikuyu) telling him ' to go and liberate his people'4.

\footnotetext{
${ }^{2}$ Interview with Prof Macharia Munene, $5^{\text {th }}$ April, 2011

${ }^{3}$ Interview with Kiemo a Sociologist and a resident of Nyahururu

${ }^{4}$ Interview with Kiemo, a sociologist and a residence of Nyahururu during the early days of the muingi-ki
} 
The Mungiki was later expanded into being a military powerful group after the 1992 and 1997 post-election violence. During this time, the Agikuyu people who were displaced from Rift Valley province migrate to Nyahururu and Nyandarua, areas that were considered proximal to Rift valley Province because these mungiki (the displaced people) was going to return to their land. While the women, elderly and the children were left behind in their new home in Nyahururu and Nyandarua the young men return to protect the properties of their people who had left Rift valley5.

During the 1997 election period, the Mungiki which was now composed of the young people who were protecting their land grew to become militarily powerful in the name of protecting what was theirs. In response the government through some leaders such as Kihika Kimani former Member of Parliament of Molo constituency came together to discredit the original Mungiki. In post-1997 election Mungiki begun to be seen as criminal gang a transformation that change the original Muingi-ki to Mungiki a feared vigilante group.

In the aftermath of 1997 election, the Mungiki youth under the leadership of Ndura Waruinge and Maina Njenga migrated to urban center since violence had ceased. In Nairobi, the Mungiki found the leader of the Tent of the Living God, Ngonya wa Gakonyo whose religion called for the revival of the Agikuyu traditional religion. The Mungiki found religious refuge in Ngonya wa Gakonyo's religious beliefs in keeping with the religious belief of the original Mungiki. As a result the transformed military youth lead by Ndura Waruinge was co-opted into the sect. In urban centers and especially in Nairobi the Mungiki was depicted as a criminal gang due to its fearlessness and military history that defined the group in Rift Valley.

As the group expanded, the fearlessness of Mungiki when faced with danger was 'stolen' by idle, unemployed and criminal youth in Nairobi who saw the name Mungiki as a means of accessing economic power. The transformed group began to use threats to extort money from matatus, businessmen and protection fees from the poor people. For these group of youth, the name 'Mungiki' spoke for them. Politically, the group was used by the politicians who saw Mungiki as means of achieving their political agenda (Oloo, 2010). Mungiki are also seen to have

\footnotetext{
${ }^{5}$ Interview with Kiemo, a sociologist and a former residence of Nyahururu during the early days of the muingi-ki
} 
political interests, in 2002 they declared their support for Uhuru Kenyatta, a KANU presidential candidate (The East African Standard, March, 2002). In the same year the leaders of Mungiki; Maina Njenga and Ndura Waruinge joined Ford-Asili political party and unsuccessfully vied for Secretary General and Vice Chairman respectively (The East African Standard, 2002).

According to Kangwanja (2003) Mungiki is interpreted in four different ways, namely; as a religious-cultural movement, local manifestation of anti-globalization, criminal gang and vigilante and a political organization. As a religious-cultural movement, it calls for return of African traditions, spiritualism and rejects Christianity as corruption of African values. Some of the traditional values they advocate for includes female circumcision, polygamy, taking of snuff, praying five times facing Mount Kenya where they allege their God dwells (Kagwanja, 2005). Mungiki as a religious cultural movement profess traditional ways of worship and view the Bible as an instrument for binding and imprisoning Africans to Christianity. As a local manifestation of anti-globalization forces they claim inheritance of Mau Mau heritage as part of their grass root for those at the economic periphery (Turner T and Brownhill, L, 2001). They also practice oathing to ensure allegiance to the group, a practice that was used by the Mau Mau. As a criminal gang and vigilante group, the Mungiki are involved in extortions, killing, kidnapping, robberies and carjacking.

\subsection{A comparative analysis of the mungiki and al-shabaab youths in armed conflict}

There are a number of similarities and difference between Mungiki and Al-shabaab, which to some extent demonstrate the difference in impact that their activities have. Similarly, the participation of youth in armed conflict and violence through Al-shabaab and Mungiki tends to concur with De Boeck (2000) proposition that youth are in indeed the breakers of themselves, the societal norms and the society as a whole.

To start with, both the militia groups rely on voluntary and forceful recruitment through coercion or by instilling fear. Their main targets are youth of school going age between 9 and 20 years. Al-shabaab as reported by a human right group forceful recruit young people to fight their 
wars while others are enticed using money, mobile phones and promise of salvation from Allah if they die fighting for Islam (Human Rights Watch, 2011). This aspect of forceful recruitment also dominates the Mungiki where those identify as possible members are often threatened to join the group while others are first befriended before being assimilated into the group. This forceful recruit implies that it is impossible to tell how many fighters believe in the ideologies of these groups. To ensure allegiance both groups have development mechanism of ensuring members remain loyal. The Al-shabaab forces their recruits to swear in the name of Allah to fight for their country. Mungiki uses oaths as means of introducing norms that have to be followed by members failure to which one is condemned to death. Hence, the purpose of oath in Mungiki is norminal.

Generally, youth constitute both male and female groups; however the membership of Mungiki and Al-shabaab is dominated by $U s h a b a b i^{6}$ that is young men. While media occasionally highlight women old and young, as members of these groups and particularly Mungiki, their role is not well known. What is however known about both groups are brutality and inhuman atrocities committed by the ushababi of Mungiki and Al-shabaab against women. For instance Al-shabaab is known for arresting, detaining and publicly flogging women caught in adultery (Human Rights Watch, 2010). Some of the Al-shabaab norms for women include wearing abaya, a Somali traditional dress that covers the whole body except face, hands and feet. The abaya is a very expensive dress and for rural women, it is an impossible dress to have yet one cannot leave the house without it. As a result, women are forced to share the dress and thus they can only leave the homes at a time. Other norms include barring women from engaging in activities that would lead them to mix with men including small-scale commercial activities as well as failing to pray at prescribed times. On its part, Mungiki which claims to be defending African tradition of the Agikuyu stripped women in public for wearing trousers which they consider to be contrary to traditional practices of the Agikuyu (Daily Nation, 2000). Mungiki has also been accused of raping women and committing other atrocities such as murder. Such behavior from the youth are not only an abrogation of the rights of women but a reflection of patriarchy interpretation of human rights, hence women rights are rights as defined by their male counterparts.

\footnotetext{
${ }^{6}$ Ushababi is Kiswahili word for a young energetic man.
} 
Both groups have also survived through instilling fear among their members and citizens. Mungiki threatens people who refuse to meet their demands such as payment of protection fees, charges for plying certain matatu routes, the police and those who wish to leave the group. Threats by the Mungiki are taken serious as seen in 2010, when Mungiki threatened to attack matatu routes as a way of revenge against police crack down on their members. This threat caused the Matatus, the public transport vehicles in Kenya to stay away from the roads for fear of attacks. Consequently, people were unable to attend to their official and non-official duties. On the other hand, Al-shabaab has continuously threatened both government officials and citizens who appear to be abrogating or breaking their idea of Sharia law. As reported by a Somali who fled from Mogadishu prayers according to Islam are offered for fear of God, however Somalia under the control of Al-shabaab, 'people pray for fear of Al-shabaab' (Human Right Watch, 2010). This purports that violent activities of the youth can have significant impact on the economic well being of a nation particularly if such activities are too often.

The sadness of this reality is that the both groups appear to be very familiar with the weaknesses and the corrupt security systems in their respective countries. In 2010, as Al-shabaab continuously threatened the soccer players and their sponsors they also arrogantly informed their victims that the non-believing police would not guarantee their security (Ravaghan, 2010). Mungiki have colluded with Kenya police at the expense of protecting the citizens (The Standard Reporter, 2010). Beyond this, atrocities have been committed before the eyes of the police yet no action have been taken. Moreover, police have been accused for committing similar atrocities to those committed by the Mungiki. This failure and the weakness of the security system to respond to the heinous acts of these groups leave citizens at the mercy of the militants. It also exposes the weakness of the state in the face of internal threats. Furthermore, citizens as seen in Kenya have been forced to respond by creating their own vigilante groups to protect themselves and their property. This further complicates the security discourse in which the state considered the sole guarantor of security within its boundaries.

Conflict and violent activities often enlist reactions from the general populace and international community; the activities of Mungiki and Al-shabaab are no exceptions. For these groups, their heinous and inhuman activities continue under, 'see, know but no tell' policy. While 
people may be well informed about whereabouts and who the members of these groups are, none is willing to speak out. This policy is supported by a story shared by a Somali man who stated that 'no one talks about Al-shabaab because people fear being attacked (Ravaghan, 2010). Similar statements have been reported on Mungiki where despite villagers being aware of whom the members are; no one dares speak about them for fear of losing their heads or those of their relatives. This is despite the heinous acts that could otherwise be described as crimes against humanity.

In their group psychology, both groups believe that by belonging and committing the atrocities they are eliminating their defined social, political or cultural evils from the larger society. For instance, the Al-shabaab believe by chopping off hands of people caught stealing or stoning women found committing adultery or by banning soccer and watching TV they are leading off their society of social misfits who are threat to Islam. Similar cases are reported of Mungiki when they strip women, who are caught wearing trousers or what they consider as men clothing unfit to worn by women. Unfortunately, their actions do not eliminate the perceived threat instead they break the social harmony as the people they continuously terrorize are their own kinsmen, friends and citizens of their own country, hence breaking the society further.

According to Huysmans (1998) security is about the pursuit of freedom from threat (1998; 227). It also means freedom from danger be it physical, direct violence or fear. In the case of Kenya and Somalia the challenge posed by the militia groups such as Mungiki and Al-shabaab are clear illustration of a growing threat to peace, freedom and stability. Since 2006 the Al-shabaab has waged war against the Transitional Government of Somalia (TFG) and called on both local and international allies to join their jihad. The Al-shabaab justified their actions by claiming that the TFG is a tool for Western powers and does not represent the interests of the people of Somalia. The war between the TFG and the Al-shabaab militant group has thus endangered the lives of Somalis and denied them a favorable environment for economic and social development. The Alshabaab is not only a threat to Somalia and its people it is also a threat to regional peace. In 2010 and 2011, Uganda and Kenya respectively were attacked by the militant group. Other than being a threat to peace and security, Al-shabaab attacks further complicates the diplomatic relationships between Somalia and its neighbors. 
Despite lacking a regional reach Mungiki has effected dangerous violent actions using cheap crude weapons. These activities were carried out in the name of revenging against government crack down, defectors, and the disobedient. The group has also continued to terrorize citizens through extortion of the so-called 'operation taxes'. These are taxes that one is supposed to pay to in order to construct a house, farm privately owned land, operate a matatu in certain routes as well as run a business. In this case, Mungiki operate as an informal government. By their violent and extortionist activities the Mungiki members makes it difficult for people to develop themselves economically, thus threatening their livelihood. By targeting those who denounce or betray the group, Mungiki makes it more difficult to heal broken families as well as the communities in the affected areas.

Both groups are also threat to peace process and reconciliation. This is through their discriminative interpretation of social activities that are considered key to conflict transformation and promotion of peace (Ahmed and Macharia, unpublished). Some of these activities/events include sports, music festivals, education and entertainment among others. Such activities like playing or watching soccer and watching television in public are banned by Al-shabaab militant group (Raghavan, 2010). During the eve of the Africa's most enthusiastic event, the World Cup, the Al-shabab member prohibited broadcasting of World Cup describing the sport as a 'satanic act' that corrupts Muslims. The group also killed and arrested people found watching the World Cup matches. National and local soccer was also a target of the group, as owners of local clubs were detained while others were tortured for what the militant considered misguiding the youth (Raghavan, 2010). The national stadiums in Mogadishu were turned into military training bases under the control of the militants.

While Mungiki members may have enjoyed watching the World Cup matches, their tendency to recruit young and energetic people who would otherwise be members of football clubs greatly hinders participation of young people in such social events. Furthermore, by recruiting members of the related families and next of kin both groups sows seeds of discord that generate deep hatred among closely related families thus causing further social discontentment at the most basic social unit, the family. It is therefore true to state that both groups are a threat to socially 
acknowledge avenues for peace and reconciliation. The two groups are also a clear indication that youth in armed conflict as perpetrators can be a cause for social disharmony and a powerful force for perpetuating a culture of violence.

As part of their historical background, youth in Africa are part and parcel of a society and more so an ethnic group. The importance of an ethnic group cannot be underestimated as it provides avenues where identities are constructed and reconstructed especially when youth seek a rationale for getting involved in conflicts. This is because in it, the interests of the ethnic group being protected are found, ethnic kingpins support or/and a solace group to fall-back to for support. While the youth may not incorporate all cultural aspects of their ethnic group in their violent activities, they may however choose selected customs and beliefs that appear rational. For instance, Mungiki ascribe to Agikuyu cultural beliefs including consumption of the tobacco snuff, praying facing Mount Kenya and gender roles (Kagwanja, 2003).

Al-shabaab on the other hand does not seem to ascribe to any ethnic group other than the Islamic religion and a political religious ideology. This is despite the fact that the Al-shabaab members, judging from appearance and the language they speak, belong to an ethnic group called Somali. The Somali ethnic group is dominant in the Horn of Africa and in some parts of Kenya. Essentially, by failing to ascribe to their ethnic group, the Al-shabaab appears to be concurring with Munene's (2010) argument that a homogeneous group called Somali collapsed when the idea of a greater Somalia state disintegrated in 1960s. Hence, for Al-shabaab their violent activities find rationale in Islamic ideologies and beliefs. Consequently their identity is constructed around religion and not ethnic group.

This construction of identity around religion rather than ethnic group has made it possible for the Al-shabaab to find allies among non-state armed groups with whom they share their ideologies. One such group is the Al-Qaeda. Al-Qaeda, an international recognized terrorist group said to be based in Afghanistan has a network across the globe (Shinn, 2010). Al-Qaeda is also on the US State Department list of terrorist organizations (Somaiya, 2010). Beyond the religious ideologies especially implementation of Sharia, the Al-shabaab overtly declared its affiliation with Al-Qaeda in 2007 causing an alarm regionally and in the global frontiers (Somaiya, 
2010; Harnich, 2010). This declaration had serious implication for the Euro-powers as they saw Al-shabaab as a serious threat to their national security and therefore global peace and security. Besides the declaration, Al-shabaab is known to have had close links with Al-Qaeda's top leadership and its activities around the world (Shinn D, 2011 ${ }^{\mathrm{i}}$ ). In the context of global security and particularly in post-9/11 the reaction by the Euro-powers that is North America and Western European countries (Munene, 2011) to non state armed groups has sinister motives and is driven by self-interest rather than the need promote stability and rebuild countries ravaged by wars.

This is because since the failed US -led mission in Somalia in 1993 the USA policy in Somalia has been hand off. However, the Al-Qaeda link with Al-shabaab and Somalia as a safe haven for Al-Qaeda activities unraveled feathers in the capitals of big powers. As noted by Munene (2011) the Euro-powers went on to create proxy states to deal with Somalia problem. The European Union and United States of America have also vowed to overwhelmingly support the TFG of Somalia financially and militarily in order to dismantle the Al-Qaeda terrorist group in Somalia. What this quick reaction by the Euro-powers to Al-shabaab insinuate is that a non-state armed group (NSAG) like Al-shabaab and Mungiki can only be a threat to global peace and security depending on their international allies and subsequent threat to Euro-powers. For example in comparison, Mungiki a nationally recognized criminal gang that have terrorized Kenyans using crude weapons and economic extortion is not a foreseeable threat to global peace and security because of its lack of international link. This is despite the heinous atrocities that have been committed by the Mungiki militias in Kenya. On its part the government of Kenya noted the activities of Mungiki with great concern while to the International community Mungiki is only a dot in the mud.

The laxity of international community to see the internal danger posed by Mungiki to the national stability in Kenya can be seen in their lack of commit to support the government in fighting the militants. While Mungiki is not the only vigilante group in Kenya it is said to have the highest number of youth membership (Kagwanja, 2005). Instead the international community uses Mungiki to depict Kenya as a failed state and discredit the government of Kenya. For instance, while post-election involved criminal gangs it is unrealistic to claim that much of the violence was 'initiated by ethnically centered gangs particularly Mungiki (Majekodunmi B, 2010). The singling 
out of one group by the international community is an indication of self-interest of the international community in small states. For the big issue here is beyond Kenya as a failed state but having a generation of young people breaking their lives and that of the society.

\subsection{Conclusion}

Despite efforts made by the TFG of Somalia and international community in the case of Somalia and the Kenyan government, the militant youth groups still remain active. For the Kenyan government, the coalition wrangles have overshadowed serious security issues such as dealing with vigilante groups. Although the Police Commissioner, Matthew Iteere has issued warning against the groups they continue with their activities though silence. One wonders where this is a reflection of a continuation of previous policies that treat youth as a periphery political actor or a weakness of the state. According to Oloo (2010) it is an indication of culture of impunity that has been engrained in Kenya's political socio-economic set up.

The state response to the militant groups, Mungiki and Al-shabaab has not been sufficient to deal with the groups. For Al-shabaab military action will continue to fail because the issues in Somalia are not just political but have also had to do with social organization in which clans and sub-clans are defining elements. Engaging all actors in peace process must therefore consider religious and contemporary leaders as well as hidden structures such as warlord and extremist religious group and mafia style business. The hidden structures are crucial because they have maintained exclusive ownership in all discussion for the fate of Somalia. Even when these groups control the process, the youth are retained as the ground troops but not the office negotiators. Hence, this creates opportunities for the reproduction of conflict and as generations of young people remain in the periphery they are key pointer to the reproduction of conflict agenda therefore engraining a culture of violence.

Evidence has shown that the continued existence of Mungiki and Al-shabaab is to some extent a result of the marginalization of the youth economically and politically. Failure to therefore address the foundation issues will maintain the groups as tools for the elite and politicians on one hand. It also makes the youth group perpetrate violence as political periphery groups and as 
criminal groups on the other hand. Therefore, crack down on group should trace their connection. The key basic tenets of International Humanitarian Law and human rights have also been ignored by Mungiki and Al-shabaab. The attacks which are affected in the name of protecting their members and their interests appear to contradict the essence of human right. In the eyes of the two groups, the mere fact that one is a human being does not guarantee protection. Instead it is ones allegiance, obedience and prescription to defined norms, values and beliefs. In addition, attack on families and relatives are a clear reflection of lack of respect for the elders. This shows that both groups need to be dealt with using both retributive and restorative legal mechanisms in order to ensure justice and healing for the affected the societies.

Moreover to achieve the UNESCO agenda for a culture of peace, education should be dialogical rather than one-way engagement. For the militia group who are outside the education system, opportunities to learn should be provided through non-formal education where community members come together to deconstruct existing conflict attitudes, beliefs and systems that perpetuate violence as a means for survival for the youth. Conflict transformation should also focus on promoting the peace, maintaining law and order, rather than the generic peace (Munene, 2009). While defining this balance is a challenge for Kenya and Somalia in the midst of globalist agenda, restoring social cohesion in the communities should be the driving force.

\section{References}

- ABC News, (2010): 'President of Botswana Says No Short, Fat Wife for Him', ABC News, $6^{\text {th }}$ December, 2010, www.abcnews.go.com

- Ali F and Macharia H, (unpublished): 'The role of women in traditional mechanism for conflict transformation' Training Material for Provincial administration and the police in Kenya, A course sponsored by UNDP and the Department of National Healing and Reconciliation, July September, 2009

- Ahmed H (2006): 'Somalia: A nation in search of a state', in Heinrich Boll Foundation, In Quest for a culture of peace in the IGAD Region: The Role of Intellectual and Scholars, Nairobi, Heinrich Boll Foundation, 163-191

- Biaya T (2000): 'Hair Statements in Urban Africa: The Beauty, the Mystic and Madam' in E, Der Plas and M Willmsen, (Eds.): The Art of African Fashion, New Jersey, African World Press 
- Bourdieu, P (1993): 'Youth is just a word', in P, Bourdieu, Sociology of Question, London, Sage Publishers

- Chigunta F, (2002): 'The Socio-Economic Situation of Youth in Africa: Problems, Prospects and Options', Draft Paper presented during the Socio-Economic Situation in Africa, $12^{\text {th }}$ July, 2002

- Comaroff J and J. L Comaroff, (2005): 'Reflections on Youth from the past to Post-colony' in A Honwana and F de Boeck (Eds.): Makers and Breakers: Children and Youth in Post-colonial Africa, Oxford, James Currey

- Daily Nation, (2000): 'Abong'o Outlaws Mungiki Meeting', Daily Nation Newspaper, $26^{\text {th }}$ October, 2000

- De Boeck, F and A, Honwana (2005): (eds.): Makers and Breakers: Children and Youth in Post-colonial Africa, Oxford, James Currey

- Engels B, (2010): 'Mapping the Phenomenon of Militias and Rebels in Africa', in W Okumu, W and A Ukelegbe (2010): (Eds.): Militia, Rebels and Islamic Militants: Human Insecurity and State Crises in Africa, Pretoria, Institute of Security Studies, pp. 69-88

- Human Right Watch, (2009): 'Stop Recruitment of Somali refugees, Rights groups urge Kenya', www.hrw.org, Accessed on $5^{\text {th }}$ April, 2011

- Huysmans J, (1998): 'Security! What do you mean? From Concept to Thick Signifier', European Journal of International Relations,

- Issa-Salwe A, (1994): The collapse of Darwish state: the impact of colonial legacy, London, HAAN Associates

- Kagwanja, M (2005): 'Power of Uhuru': Youth Identity and Generational Politics in Kenya's 2002 Elections', African Affairs, Vol. 105 No. 418, pp.51-75

- Kagwanja, M (2002);

- Kagwanja M, (2003): 'Facing Mount Kenya or Facing Mecca? The Mungiki, Ethnic violence and the Politics of the Moi Succession in Kenya: 1987-2002', African Affairs, Vol. 102, pp.2549

- Kataaib (2008): 'Somalia: Al-shabab leader Abu Mansur Addresses rally in Southern city of Marka, Kataaib.net, $14^{\text {th }}$ November, 2010

- Katagiri N, (2010): 'Containing Somali insurgency: learning from the British experience in Somaliland, African Security Review, Vol. 19, No. 1, March 2010, pp.33-45

- Kobia S (undated): 'Violence in Africa', www.wcc-coe.org/wcc, Accessed on 22nd, November, 2010

- Majekodunmi B (2010); 'Report to the General Secretary on the situation in Kenya by the Special Advisor on the Prevention of Genocide, $29^{\text {th }}$ February, 2008.

- Mkandawire, T (1996): 'Experience in Youth Policy and Programme in Commonwealth Africa', Unpublished Policy Document Prepared for the Commonwealth Youth programme Department

- Munene, M (2011):

- Munene M, (2011): 'Why Arab Youth are fighting?' Business Daily, Tuesday February $22^{\text {nd }}$ 2011

- Munene M, (2010) 'How Somalia slowly disintegrated into small pieces of troubled nations', African Review, $1^{\text {st }}$ July, 2010, www.africanreview.com 
- Munene, $M$ (1995): The Politics of Transition: 1995-1998, Nairobi, University of Nairobi Press

- Nyatuga W, (2001): Revisiting our indigenous shrines through Mungiki', African Affairs, Vol. 100, pp.453-467

- Njoroge J, (2010): 'Art and Culture: Museveni to Copyright rap hit as rival prepare to tell him off', African Review, $28^{\text {th }}$ October, 2010

- Okumu, W and A Ukelegbe (2010): (eds.): Militia, Rebels and Islamic Militants: Human Insecurity and State Crises in Africa, Pretoria, Institute of Security Studies

- Oloo A, (2010): 'Party Mobilization and Membership: Old and New Identities in Kenya Politics', in K Kanyinga and Okello D, (Eds.): Tensions and Reversals in Democratic Transitions: The Kenya 2007 General Elections, Institute of Diplomatic Studies, University of Nairobi, pp.31-60

- Oloo A, (2010): 'Marginalization and the rise of militia groups in Kenya: Mungiki and Sabaot Land defence Force', in W Okumu and A Ukelegbe (2010): (Eds.): Militias, Rebels and Islamist Militant: Human Insecurity and State Crises in Africa, Pretoria, Institute of Security Studies, pp. 147-181

- Raghavan, S (2010): 'Under Threat of violence, Somalis play soccer or watch at their peril', Washington Post, $11^{\text {th }}$ July, 2010, www.washingtonpost.com, (Accessed 30 ${ }^{\text {th }}$ March, 2011).

- Shinn D, (2011): 'Al-shabab a Foreign Threat to Somalia', Foreign Policy Research Institute, Elsevier, Spring, 2011, pp.203-215

- Shiundu, A (2011): 'Kenya: House halts business to discuss Sonko's dressing', Daily Nation, $1^{\text {st }}$ March, 2011

- Somaiya R (2010); 'Who is Al-shabab?', Newsweek, $12^{\text {th }}$ July, 2010, www.newsweek.com

- The Standard Reporter, (2010): 'Trail of fear as Mungiki returns to full business', The Standard, $23^{\text {rd }}$ November, 2010

- The Standard, (2002): 'Mungiki to support KANU, Saitoti and Uhuru in poll, The Standard, $4^{\text {th }}$ March, 2002.

- Thurston A, (2010): 'Somalia terrorist activity in US raises concerns, questions', www.csmonitor.com, Accessed on $22^{\text {nd }}$ March, 2011

- UN, (2009): 'World Population Prospects: The 2008 Revision', Population Newsletter, United Nations, Department of Economic and Social Affairs No.87, June, 2009

- UN, (1996): 'World Programme of action for youth to the Year 2000 and beyond', Resolution Adopted by UN General Assembly, A/RES/50/81, www.canadiancrc.com, Accessed 7th April, 2011

- UNDP and GoK, (2007): 'The Youth in Africa: A Threat to Security or a Force for Peace?', Conference background Paper, www.undp.org, Accessed $22^{\text {nd }}$ November, 2010

- Urbach F (1991): 'Potential Health Effects of Climate Change: Effects of Increased Ultraviolet Radiation on Man', Environmental Health Perspectives, Vol. 96, pp. 175-176

- Wanderi, C (undated): Mungiki: Legitimate or Criminal? The Africa Executive, www.africanexecutive.com/modules/magazine, Accessed on $3^{\text {rd }}$ April, 2011. 